\title{
PENDAMPINGAN IMPLEMENTASI PENILAIAN PENDIDIKAN DI PERGURUAN MUHAMMADIYAH WIYUNG SURABAYA
}

\author{
Oleh: \\ Rudy Kustijono ${ }^{1}$, Hermin Budiningarti', Titin Sunarti ${ }^{3}$ \\ 1,2,3 Jurusan Fisika FMIPA Unesa \\ ${ }^{1}$ rudyunesa@gmail.com
}

\begin{abstract}
Abstrak
Telah dilakukan kegiatan pengabdian kepada masyarakat (PKM) di Perguruan Muhammadiyah Wiyung Surabaya yang membawahi SD Muhammadiyah 15 Surabaya, SMP Muhammadiyah 17 Surabaya, dan SMA Muhammadiyah 9 Surabaya. Tujuan kegiatan adalah melakukan pendampingan kepada para guru di Perguruan Muhammadiyah Wiyung Surabaya dalam mengimplementasikan penilaian pendidikan yang sesuai standar Kurikulum 13. Secara umum target program adalah diperolehnya wawasan dan kemampuan para guru di lembaga tersebut terkait implementasi penilaian pendidikan dalam pembelajaran yang memenuhi standar. Luaran yang dihasilkan program adalah produk yang berupa instrumen penilaian beserta rubriknya yang memenuhi standar. Dari kegiatan PKM dapat ditarik kesimpulan bahwa: Semua guru di SD Muhammadiyah 15 Surabaya telah mempunyai pemahaman yang baik terhadap penilaian pendidikan yang sesuai standar, semua guru telah mengembangkan instrumen penilaian pendidikan beserta rubriknya yang sesuai standar, dan semua guru telah mengimplementasikan penilaian pendidikan yang sesuai standar, sedangkan guru di SMP Muhammadiyah 17 Surabaya dan SMA Muhammadiyah 9 Surabaya baru sebagian kecil saja yang mempunyai pemahaman yang baik terhafap penilaian pendidikan yang sesuai standar, sebagian kecil saja yang mengembangkan instrumen penilaian pendidikan yang sesuai standar, dan sebagian kecil saja yang mengimplementasikan penilaian pendidikan yang sesuai standar. Namun demikian, semua guru di Perguruan Muhammadiyah Wiyung Surabaya memberikan respon yang baik terhadap pelaksanaan PKM di lembaga tersebut.
\end{abstract}

Kata Kunci: standar, penilaian, pendidikan

\section{Abstract}

A Community Service (PKM) has been conducted in Perguruan Muhammadiyah, Wiyung Surabaya which oversees SD Muhammadiyah 15 Surabaya, SMP Muhammadiyah 17 Surabaya, and SMA Muhammadiyah 9 Surabaya. Its objective is to provide guidance to teachers in Perguruan Muhammadiyah, Wiyung Surabaya in implementing educational assessment which isi in accordance with curriculum 13. In general, the program's target is that the teachers are able to obtain knowledge and skills regarding the implementation of educational assessment in teaching learning proccess that meet the standards. The outcome is a product in the form of columns and their assessment instruments that meet the standards. From the activity of PKM, it can be concluded that: All teachers in SD Muhammadiyah 15 Surabaya already have good understanding of assessment which is appropriate with educational standards, all teachers have developed an assessment instrument of education along with the columns that follow the standard, and all teachers have implemented educational assessment standards, the other result is that, only few of teachers in SMP Muhammadiyah 17 Surabaya and SMA Muhammadiyah 9 Surabaya who have good understanding against assessment which is appropriate with educational standards, few of them develop assessment instruments which is appropriate with educational standards, and few of them implement educational assessment which is in accordance to the standard. However, all teachers at the Perguruan Muhammadiyah, Wityung, Surabaya gave good responses to the implementation of PKM.

Keywords: standards, assessment, education

\section{PENDAHULUAN}

Perguruan Muhammadiyah Wiyung Surabaya adalah perguruan yang dibawahi oleh Majelis Pendidikan Dasar dan Menengah Muhammadiyah Wiyung Surabaya. Perguruan tersebut memiliki tiga sekolah dari jenjang yang berbeda, yaitu SD Muham- madiyah 15 Surabaya yang didirikan pada tahun 1951, SMP Muhammadiyah 17 Surabaya yang didirikan pada tahun 2007, dan SMA Muhammadiyah 9 Surabaya yang didirikan pada tahun 2011.

Pada tahun pelajaran 2013-2014, SD Muhammadiyah 15 Surabaya telah mengimplementasikan Kurikulum 2013 dan saat ini 
telah diterapkan pada kelas I, II, IV, dan V. Sementara itu, SMP Muhammadiyah 17 Surabaya dan SMA Muhammadiyah 9 Surabaya masih belum mengimplementasikan Kurikulum 2013 tersebut. Kendala yang dihadapi Perguruan Muhammadiyah Wiyung Surabaya adalah minimnya kemampuan para guru dalam mengimplementasikan Kurikulum 2013 khususnya yang berkaitan dengan penilaian yang sesuai dengan tuntutan Kurikulum 2013 tersebut. Demikian pula untuk para guru di SMP Muhammadiyah 17 Surabaya dan SMA Muhammadiyah 9 Surabaya, penerapan penilaian pendidikan belum seperti yang diharapkan. Penilaian masih didominasi oleh aspek pengetahuan semata.

Rujukan utama penilaian pendidikan adalah Permendikbud No. 66 Tahun 2013 tentang standar penilaian pendidikan yang telah diregulasi dengan Permendikbud No.104 Tahun 2014 yang intinya adalah bahwa penilaian pendidikan merupakan proses pengumpulan dan pengolahan informasi untuk mengukur pencapaian hasil belajar peserta didik yang harusnya mengarah pada penilaian otentik. Permasalahan yang dihadapi oleh para guru di Perguruan Muhammadiyah Wiyung Surabaya adalah kurangnya pemahaman tentang penilaian otentik tersebut.

Berkaitan dengan permasalahan yang dihadapi tersebut, Perguruan Tinggi (Unesa) selaku lembaga yang memiliki kelayakan akademis tentang ilmu pengetahuan termasuk masalah yang berkaitan dengan penilaian pendidikan amatlah diperlukan kiprahnya dalam ikut membantu mengatasi masalah yang dihadapi sekolah dan lembaga pendidikan di masyarakat. Untuk itu kegiatan pengabdian kepada masyarakat dari perguruan tinggi (Unesa) yang menerapkan hasil penelitiannya sangatlah diperlukan.

Salah satu alasan pentingnya Kurikulum 2013 adalah bahwa generasi muda Indonesia perlu disiapkan dalam kompetensi sikap, pengetahuan, dan keterampilan. Pendekatan saintifik dalam Kurikulum 2013 akan diberlakukan kepada semua mata pelajaran untuk semua jenjang. Sebagian besar kalangan termasuk para pakar memandang pendekatan saintifik sebagai discovery method atau metode penemuan.

Pendekatan saintifik tersebut sebenarnya sesuai dengan pengembangan kompetensi yang diperlukan untuk menghadapi abad 21 . Menurut Trilling dan Hood (1999), para peramal masa depan (futurist) mengatakan bahwa abad 21 sebagai abad pengetahuan, karena pengetahuan akan menjadi landasan utama segala aspek kehidupan. Ruiz dan Primo (2009) menyatakan bahwa pada tahun 2007, The National Academies menyelenggarakan lokakarya hasil penelitian yang terkait dengan keterampilan masa depan. Hasil lokakarya tersebut menyimpulkan bahwa setidaknya diperlukan lima keterampilan yang secara luas diperlukan di berbagai jenis pekerjaan, yaitu: adaptability, complex communications/social skills, nonroutine problem solving, self-management/ self-development, dan systems thinking. De Vito (1989) menyatakan bahwa untuk mengantisipasi abad 21, model pembelajaran yang diperlukan adalah yang memungkinkan terbudayakannya kecakapan berpikir ilmiah, terkembangkannya "sense of inquiry" dan kemampuan berpikir kreatif siswa.

Untuk menghasilkan insan yang kreatif dalam proses pembelajaran, Kurikulum 2013 mendukung pendapat Dyers, bahwa kreativitas dapat diperoleh melalui kegiatan (Kemdikbud, 2012):

1. Observing (mengamati)

2. Questioning (menanya)

3. Associating (menalar)

4. Experimenting (mencoba)

5. Networking (membentuk jejaring)

Oleh karena itu, pembelajaran harus mengedepankan pengalaman personal melalui proses mengamati, menanya, menalar, dan mencoba (observation based learning) untuk meningkatkan kreativitas peserta didik. Disamping itu, dibiasakan pula bagi peserta didik untuk bekerja dalam jejaringan melalui collaborative learning.

Untuk menghasilkan insan yang kreatif tersebut, sistem penilaian pembelajaran dalam Kurikulum 2013 mendukung pendapat Sharp, (2004), yaitu Developing young children's creativity, what can we learn from research, yaitu guru dapat membuat peserta didik berani berperilaku kreatif melalui (Kemdikbud, 2012):

1. Tugas yang tidak hanya memiliki satu jawaban tertentu yang benar (memiliki banyak/semua jawaban benar),

2. Mentolerir jawaban yang nyeleneh,

3. Menekankan pada proses bukan hanya hasil saja, memberanikan peserta didik untuk mencoba, untuk menentukan sendiri yang kurang jelas/lengkap informasinya, untuk memiliki interpretasi sendiri terkait dengan pengetahuan atau kejadian yang diamatinya, dan 
4. Memberikan keseimbangan antara yang terstruktur dan yang spontan/ekspresif.

Oleh karena itu, Kurikulum 2013 menggunakan standar penilaian yang mencakup pertanyaan yang tidak memiliki jawaban tunggal, memberi nilai bagi jawaban nyeleneh, menilai proses pengerjaannya dan bukan hanya hasilnya, serta penilaian yang spontanitas/ekspresif, dll.

Penilaian (assessment) adalah penerapan berbagai cara dan penggunaan beragam alat penilaian untuk memperoleh informasi tentang sejauh mana hasil belajar peserta didik atau ketercapaian kompetensi (rangkaian kemampuan) peserta didik. Penilaian menjawab pertanyaan tentang sebaik apa hasil atau prestasi belajar seorang peserta didik. Hasil penilaian dapat berupa nilai kualitatif (pernyataan naratif dalam katakata) dan nilai kuantitatif (berupa angka). Pengukuran berhubungan dengan proses pencarian atau penentuan nilai kuantitatif tersebut.

Penilaian pendidikan adalah proses pengumpulan dan pengolahan informasi untuk menentukan pencapaian hasil belajar peserta didik. Penilaian hasil belajar peserta didik dilaksanakan berdasarkan standar penilaian pendidikan yang berlaku secara nasional. Standar penilaian pendidikan adalah standar nasional pendidikan yang berkaitan dengan mekanisme, prosedur, dan instrumen penilaian hasil belajar peserta didik.

Penilaian hasil belajar pada dasarnya adalah mempermasalahkan bagaimana pengajar (guru) dapat mengetahui hasil pembelajaran yang telah dilakukan. Pengajar harus mengetahui sejauh mana pebelajar (learner) telah mengerti bahan yang telah diajarkan atau sejauh mana tujuan/ kompetensi dari kegiatan pembelajaran yang dikelola dapat dicapai. Tingkat pencapaian kompetensi atau tujuan instruksional dari kegiatan pembelajaran yang telah dilaksanakan itu dapat dinyatakan dengan nilai.

Menurut Permendikbud No. 66 th 2013 tentang Standar Penilaian yang diregulasi dengan Permendikbud No 104 th 2014, disebutkan bahwa Standar Penilaian Pendidikan adalah kriteria mengenai mekanisme, prosedur, dan instrumen penilaian hasil belajar dam pembelajaran peserta didik. Penilaian pendidikan sebagai proses pengumpulan dan pengolahan informasi untuk mengukur pencapaian hasil belajar peserta didik mencakup: penilaian otentik, penilaian diri, penilaian berbasis portofolio, ulangan harian, ulangan tengah semester, ulangan akhir semester, ujian tingkat kompetensi, ujian mutu tingkat kompetensi, ujian nasional, dan ujian sekolah/madrasah. Pendekatan penilaian yang digunakan adalah penilaian acuan kriteria (PAK). PAK merupakan penilaian pencapaian kompetensi yang didasarkan pada kriteria ketuntasan minimal (KKM). KKM merupakan kriteria ketuntasan belajar minimal yang ditentukan oleh satuan pendidikan dengan mempertimbangkan karakteristik Kompetensi Dasar yang akan dicapai, daya dukung, dan karakteristik peserta didik. Beberapa hal penting terkait penilaian yang perlu diperhatikan, yaitu:

1. Penilaian hasil belajar peserta didik mencakup kompetensi sikap, pengetahuan, dan keterampilan yang dilakukan secara berimbang, sehingga dapat digunakan untuk menentukan posisi relatif setiap peserta didik terhadap standar yang telah ditetapkan. Cakupan penilaian merujuk pada ruang lingkup materi, kompetensi mata pelajaran/kompetensi muatan/kompetensi program, dan proses.

2. Pendidik melakukan penilaian kompetensi sikap melalui observasi, penilaian diri, penilaian "teman sejawat" (peer evaluation) oleh peserta didik dan jurnal.

3. Pendidik menilai kompetensi pengetahuan melalui tes tulis, tes lisan, dan penugasan.

4. Pendidik menilai kompetensi keterampilan melalui penilaian kinerja, yaitu penilaian yang menuntut peserta didik mendemonstrasikan suatu kompetensi tertentu dengan menggunakan tes praktik, projek, dan penilaian portofolio.

5. Instrumen penilaian harus memenuhi persyaratan: 1) substansi yang merepresentasikan kompetensi yang dinilai; 2) konstruksi yang memenuhi persyaratan teknis sesuai dengan bentuk instrumen yang digunakan; dan 3) penggunaan bahasa yang baik dan benar serta komunikatif sesuai dengan tingkat perkembangan peserta didik.

Berdasarkan penelitian yang telah dilakukan (Kustijono, 2014) diketahui bahwa secara umum para guru sekolah sasaran masih belum dapat melaksanakan penilaian pembelajaran yang sesuai dengan Kurikulum 2013 secara maksimal. Masih ada beberapa unsur dalam penilaian pembelajaran yang belum sesuai standar penilaian yang ditetapkan. Penyebab utama belum maksimalnya pelaksanaan penilaian pembelajaran sesuai Kurikulum 2013 adalah belum 
maksimalnya pemahaman para guru sekolah sasaran terkait penilaian pembelajaran yang sesuai Permendikbud No. 66 Tahun 2013 tentang Standar Penilaian yang kemudian diregulasi dengan Permendikbud 104 tahun 2014, di samping kurangnya infrastruktur yang mendukung keberhasilan implementasi Kurikulum 2013 tersebut.

Berdasarkan analisis situasi terhadap potensi mitra sasaran (SDM, sarpras, dan sumber dana) dan analisis terhadap peluang peran tim pelaksana PKM berdasarkan hasil penelitian sebagai modal dasar dalam pelaksanaan PKM tersebut, masalah yang dapat dirumuskan adalah: Bagaimana wawasan dan kemampuan para guru di Perguruan Muhammadiyah Wiyung Surabaya dalam mengembangkan instrumen penilaian beserta rubriknya yang memenuhi standar penilaian pendidikan, yang meliputi:

1. Bagaimana wawasan dan kemampuan para guru di Perguruan Muhammadiyah Wiyung Surabaya terhadap penilaian pembelajaran yang memenuhi standar?

2. Bagaimana para guru di Perguruan Muhammadiyah Wiyung Surabaya dalam mengembangkan instrumen penilaian pendidikan dan rubriknya yang memenuhi standar?

3. Bagaimana penerapan penilaian pendidikan dalam pembelajaran di Perguruan Muhammadiyah Wiyung Surabaya yang memenuhi standar?

4. Bagaimana respon para guru di Perguruan Muhammadiyah Wiyung Surabaya terhadap pelaksanaan PKM di lembaga tersebut?

Secara umum target program yang dilaksanakan adalah diperolehnya wawasan dan kemampuan para guru di Perguruan Muhammadiyah Wiyung Surabaya terkait penerapan penilaian pendidikan dalam pembelajaran yang memenuhi standar. Secara rinci target yang ingin diperoleh adalah:

1. Wawasan para guru di Perguruan Muhammadiyah Wiyung terhadap penilaian pembelajaran yang memenuhi standar.

2. Pengembangan instrumen penilaian yang memenuhi standar beserta rubriknya oleh para guru di Perguruan Muhammadiyah Wiyung Surabaya.

3. Penerapan penilaian pendidikan dalam pembelajaran oleh para guru di Perguruan Muhammadiyah Wiyung Surabaya yang memenuhi standar
4. Respon dari para guru di Perguruan Muhammadiyah Wiyung Surabaya terhadap kegiatan tim PKM di lembaga tersebut.

Luaran dari program pengabdian kepada masyarakat secara umum dapat berupa jasa, metode, dan produk. Luaran yang dihasilkan program ini adalah produk yang berupa instrumen penilaian beserta rubriknya yang memenuhi standar penilaian pendidikan.

Produk yang dihasilkan dari program ini akan sangat bermanfaat bagi lembaga mitra, karena dapat memberikan nilai tambah pada brand image sebagai sekolah-sekolah yang unggul dan memenuhi standar nasional pendidikan. Dari segi pengembangan SDM, produk yang dihasilkan tersebut dapat menggambarkan adanya peningkatan kemampuan dari para guru, sehingga diharapkan dapat meningkatnya kualitas pembelajaran yang ada.

\section{METODE PELAKSANAAN}

Khalayak sasaran dalam kegiatan PKM ini adalah para guru di sekolah-sekolah yang dinaungi Perguruan Muhammadiyah Wiyung Surabaya, yaitu guru SD Muhammadiyah 15 Surabaya, guru SMP Muhammadiyah 17 Surabaya, dan guru SMA Muhammadiyah 9 Surabaya.

Dari berbagai metode kegiatan yang dapat dipilih dalam kegiatan PKM, dengan memperhatikan berbagai pertimbangan, maka tim PKM memilih metode kegiatan sebagai berikut:

1. Mereview wawasan para guru di Perguruan Muhammadiyah Wiyung Surabaya terhadap penerapan penilaian pendidikan dalam pembelajaran dan memberikan pembekalan atau penguatan terhadap wawasan yang telah dimiliki oleh para guru tersebut.

2. Melatih para guru di Perguruan Muhammadiyah Wiyung Surabaya terhadap penerapan penilaian pendidikan dalam pembelajaran dan memberikan penguatan bagi para guru yang telah memiliki kemampuan tersebut.

3. Mendampingi para guru di Perguruan Muhammadiyah Wiyung Surabaya dalam mengembangkan instrumen penilaian dan rubriknya dalam pembelajarannya.

4. Memantau para guru di Perguruan Muhammadiyah Wiyung Surabaya dalam menerapkan instrumen penilaian dan rubriknya dalam pembelajarannya di kelas. 
5. Memantau respon siswa terhadap penerapan instrumen penilaian dan rubriknya dalam pembelajaran di kelas oleh para guru di Perguruan Muhammadiyah Wiyung Surabaya.

Mengingat perbedaan karakteristik antara guru mapel dan guru kelas, dan agar hasil yang diperoleh dari kegiatan pengabdian kepada masyarakat ini dapat maksimal, maka kegiatan pendampingan dikelompokkan menjadi dua, yaitu:

1. Kelompok guru kelas yang pesertanya berasal dari guru-guru SD Muhammadiyah 15 Surabaya.

2. Kelompok guru mapel yang pesertanya berasal dari guru-guru SMP Muhammadiyah 17 Surabaya dan SMA Muhammadiyah 9 Surabaya.

\section{HASIL DAN PEMBAHASAN}

Setelah melaksanakan kegiatan PKM di Perguruan Muhammadiyah Wiyung Surabaya selanjutnya dilakukan refleksi terhadap wawasan dan kemampuan para guru, pengembangan instrumen penilaian beserta rubriknya, dan implementasi penilaian yang sesuai standar. Standar penilaian pendidikan yang dimaksud adalah mengacu pada Permendiknas No. 20 Tahun 2007, Permendikbud No. 66 Tahun 2013, dan Permendikbud No.104 tahun 2014. Sasaran evaluasi adalah sekolah-sekolah dibawah Perguruan Muhammadiyah Wiyung Surabaya yaitu: SD Muhammadiyah 15 Surabaya, SMP Muhammadiyah 17 Surabaya, dan SMA Muhammadiyah 9 Surabaya.

Refleksi terkait wawasan dan kemampuan para guru terhadap penilaian pendidikan yang sesuai standar di Perguruan Muhammadiyah Wiyung Surabaya dilakukan melalui wawancara. Hasil refleksi yang diperoleh dapat dirangkum dalam Tabel 1.

Tabel 1. Refleksi Wawasan dan Kemampuan Guru Terhadap Penilaian Pendidikan

\begin{tabular}{lccc}
\hline \multicolumn{1}{c}{ Indikator } & \multicolumn{2}{c}{ Jumlah guru dengan pemahaman baik } \\
\cline { 2 - 4 } & SDM 15 & SMPM 17 & SMAM 9 \\
\hline Pemahaman penilaian otentik & $100 \%$ & $50 \%$ & $50 \%$ \\
\hline Pemahaman penilaian diri & $100 \%$ & $50 \%$ & $50 \%$ \\
\hline Pemahaman penilaian portofolio & $100 \%$ & $25 \%$ & $25 \%$ \\
\hline Pemahaman konsep ulangan harian & $100 \%$ & $100 \%$ & $100 \%$ \\
\hline Pemahaman konsep ulangan tengah semester (UTS) & $100 \%$ & $100 \%$ & $100 \%$ \\
\hline Pemahaman konsep ulangan akhir semester & $100 \%$ & $100 \%$ & $100 \%$ \\
\hline Pemahaman konsep ujian tingkat kompetensi & $100 \%$ & $50 \%$ & $50 \%$ \\
\hline Pemahaman konsep penilaian projek & $100 \%$ & $50 \%$ & $50 \%$ \\
\hline Pemahaman pengolahan nilai & $100 \%$ & $75 \%$ & $75 \%$ \\
\hline Pemahaman konsep remedial dan pengayaan & $100 \%$ & $75 \%$ & $75 \%$ \\
\hline
\end{tabular}

Berdasarkan hasil refleksi tersebut dapat diperoleh gambaran bahwa guru yang telah mempunyai pemahaman baik terhadap penilaian pendidikan yang sesuai standar adalah berasal dari SD Muhammadiyah 15 Surabaya. Namun, hal tersebut dapat dimaklumi karena sekolah tersebut telah menggunakan Kurikulum 2013, sehingga sangat mendorong para guru di sekolah tersebut untuk berusaha memahami penilaian pendidikan yang sesuai standar sebagai bagian yang tak terpisahkan dari penggunaan Kurikulum 2013 tersebut. Sementara itu guru yang berasal dari SMP Muhammadiyah 17 Surabaya dan SMA Muhammadiyah 9
Surabaya baru sebagian saja yang sudah memahami dengan baik penilaian pendidikan yang sesuai standar.

Refleksi pengembangan instrumen dan rubrik penilaian yang sesuai standar oleh para guru di Perguruan Muhammadiyah Wiyung Surabaya dilakukan melalui observasi instrumen penilaian dan rubrik yang telah dibuat oleh para guru. Hasil refleksi yang terkait pengembangan instrumen penilaian pendidikan beserta rubriknya yang sesuai standar dapat dirangkum dalam Tabel 2. 
Tabel 2. Refleksi Pengembangan Instrumen dan Rubrik Penilaian

\begin{tabular}{cclccc}
\hline \multirow{2}{*}{ Komponen } & \multicolumn{1}{c}{ Indikator } & \multicolumn{2}{c}{ Jumlah Guru Pengembang } \\
\cline { 2 - 5 } $\begin{array}{c}\text { Penilaian } \\
\text { sikap }\end{array}$ & a. & $\begin{array}{l}\text { Instrumen penilaian sikap yang sesuai dengan } \\
\text { kaidah }\end{array}$ & $80 \%$ & $40 \%$ & $40 \%$ \\
\cline { 2 - 5 } & b. & $\begin{array}{l}\text { Rubrik penilaian sikap yang sesuai dengan } \\
\text { kaidah }\end{array}$ & $80 \%$ & $40 \%$ & $40 \%$ \\
\hline $\begin{array}{c}\text { Penilaian } \\
\text { pengetahuan }\end{array}$ & a. & $\begin{array}{l}\text { Instrumen penilaian pengetahuan yang sesuai } \\
\text { dengan kaidah }\end{array}$ & $100 \%$ & $60 \%$ & $60 \%$ \\
\cline { 2 - 5 } & b. & $\begin{array}{l}\text { Rubrik penilaian pengetahuan yang sesuai } \\
\text { dengan kaidah }\end{array}$ & $100 \%$ & $30 \%$ & $30 \%$ \\
\hline $\begin{array}{c}\text { Penilaian } \\
\text { keterampilan }\end{array}$ & a. $\begin{array}{l}\text { Instrumen penilaian keterampilan yang sesuai } \\
\text { dengan kaidah }\end{array}$ & $100 \%$ & $60 \%$ & $60 \%$ \\
\cline { 2 - 5 } & b. & $\begin{array}{l}\text { Rubrik penilaian keterampilan yang sesuai } \\
\text { dengan kaidah }\end{array}$ & $100 \%$ & $30 \%$ & $30 \%$ \\
\hline
\end{tabular}

Berdasarkan hasil refleksi tersebut dapat diperoleh gambaran bahwa secara umum para guru dari sekolah-sekolah yang dinaungi lembaga tersebut belum sepenuhnya mengembangkan instrumen penilaian pendidikan beserta rubriknya sesuai standar. Para guru yang semuanya telah mengembangkan instrumen penilaian pendidikan beserta rubriknya sesuai dengan standar barulah para guru SD Muhammadiyah 15 Surabaya. Penggunaan Kurikulum 2013 di sekolah tersebut memaksa para guru untuk mengembangkan instrumen penilaian pendidikan beserta rubriknya yang sesuai standar karena merupakan bagian yang tak terpisahkan dari penggunaan Kurikulum 2013 Para guru yang merupakan guru kelas tersebut cukup terbantu dalam mengembangkan instrumen dan rubrik penilaian karena dalam buku siswa dan buku guru banyak dijumpai contohcontohnya. Para guru di SD Muhammadiyah 15 Surabaya telah mampu mengembangkan penilaian yang meliputi kompetensi sikap, pengetahuan, dan keterampilan instrumen dan rubrik yang sesuai dengan kaidah. Kendala yang dihadapi para guru di sekolah tersebut adalah belum dapat mengembangkan penilaian diri dan penilaian teman sejawat dari para siswa karena sulit diperoleh tingkat objektivitasnya.

Sementara itu, para guru SMP Muhammadiyah 17 Surabaya dan SMA Muhammadiyah 9 Surabaya masih belum banyak yang mengembangkan instrumen penilaian beserta rubriknya yang sesuai dengan standar. Penggunaan kembali KTSP di sekolah-sekolah tersebut tampaknya telah menghilangkan gairah para guru dalam mengembangkan instrumen penilaian beserta rubriknya yang sesuai dengan standar.

Refleksi implementasi penilaian pendidikan yang sesuai standar di Perguruan Muhammadiyah Wiyung Surabaya dilakukan melalui observasi dokumentasi penilaian dan hasil karya siswa yang dipamerkan. Hasil refleksi yang terkait dengan implementasi penilaian pendidikan yang sesuai standar dapat dirangkum dalam Tabel 3.

Tabel 3. Refleksi Penerapan Penilaian Pendidikan

\begin{tabular}{|c|c|c|c|c|c|}
\hline \multirow{2}{*}{\multicolumn{2}{|c|}{ Komponen }} & \multirow{2}{*}{ Indikator } & \multicolumn{3}{|c|}{ Capaian } \\
\hline & & & SDM 15 & SMPM 17 & SMAM 9 \\
\hline \multirow{4}{*}{$\begin{array}{l}\text { Penilaian } \\
\text { oleh guru }\end{array}$} & \multirow[t]{2}{*}{$\begin{array}{l}\text { Penilaian } \\
\text { kompetensi } \\
\text { sikap }\end{array}$} & $\begin{array}{l}\text { a. Terlaksananya penilaian sikap } \\
\text { selama proses pembelajaran } \\
\text { dengan teknik observasi dan } \\
\text { jurnal. }\end{array}$ & $100 \%$ & $60 \%$ & $60 \%$ \\
\hline & & $\begin{array}{l}\text { b. Terdokumentasikannya hasil } \\
\text { penilaian kompetensi sikap. }\end{array}$ & $100 \%$ & $100 \%$ & $100 \%$ \\
\hline & \multirow[t]{2}{*}{$\begin{array}{l}\text { Penilaian } \\
\text { pengetahuan }\end{array}$} & $\begin{array}{l}\text { a. Terlaksananya penilaian } \\
\text { pengetahuan dengan tes lisan, } \\
\text { tes tulis, dan penugasan }\end{array}$ & $100 \%$ & $100 \%$ & $100 \%$ \\
\hline & & $\begin{array}{l}\text { b. Terdokumentasikannya hasil } \\
\text { penilaian penguasaan } \\
\text { pengetahuan. }\end{array}$ & $100 \%$ & $100 \%$ & $100 \%$ \\
\hline
\end{tabular}




\begin{tabular}{|c|c|c|c|c|}
\hline \multirow{2}{*}{ Komponen } & \multirow{2}{*}{ Indikator } & \multicolumn{3}{|c|}{ Capaian } \\
\hline & & SDM 15 & SMPM 17 & SMAM 9 \\
\hline \multirow[t]{2}{*}{$\begin{array}{l}\text { Penilaian } \\
\text { keterampilan }\end{array}$} & $\begin{array}{l}\text { a. Terlaksananya penilaian } \\
\text { keterampilan dengan praktik, } \\
\text { projek, dan portofolio. }\end{array}$ & $100 \%$ & $100 \%$ & $100 \%$ \\
\hline & $\begin{array}{l}\text { b. Terdokumentasikannya hasil } \\
\text { penilaian keterampilan. }\end{array}$ & $100 \%$ & $100 \%$ & $100 \%$ \\
\hline \multirow{2}{*}{$\begin{array}{l}\text { Penilaian } \\
\text { oleh siswa }\end{array}$} & $\begin{array}{l}\text { a. Dilaksanakannya penilaian } \\
\text { melalui penilaian diri dan } \\
\text { penilaian antar teman. }\end{array}$ & $20 \%$ & $20 \%$ & $20 \%$ \\
\hline & $\begin{array}{l}\text { b. Terdokumentasikannya hasil } \\
\text { penilaian oleh siswa. }\end{array}$ & $20 \%$ & $20 \%$ & $20 \%$ \\
\hline
\end{tabular}

Berdasarkan hasil refleksi tersebut dapat diperoleh gambaran bahwa secara umum para guru dari sekolah-sekolah yang dinaungi lembaga tersebut belum sepenuhnya mengimplementasikan penilaian pendidikan sesuai standar. Para guru yang semuanya telah mengimplementasikan penilaian pendidikan yang sesuai standar barulah SD Muhammadiyah 15 Surabaya. Penggunaan Kurikulum 2013 di sekolah tersebut memaksa para guru untuk mengimplementasikan penilaian pendidikan yang sesuai standar karena merupakan bagian yang tak terpisahkan dari penggunaan Kurikulum 2013 Di sekolah tersebut telah dapat menerapkan penilaian otentik yang dapat dilihat dari karyakarya siswa yang dipajang di masing-masing kelas.

Sementara itu, penilaian pendidikan yang sesuai standar masih belum dapat diimplementasikan oleh guru di SMP Muhammadiyah 17 Surabaya dan SMA Muhammadiyah 9 Surabaya. Alasan utama para guru di sekolah-sekolah tersebut belum dapat mengimplementasikan penilaian pendidikan yang sesuai standar adalah karena sekolah-sekolah tersebut kembali menggunakan KTSP walaupun sebelumnya sempat menggunakan Kurikulum 2013 selama satu semester. Pada saat menggunakan Kurikulum 2013, para guru sebenarnya telah diberikan bekal cukup untuk mengimplementasikan penilaian pendidikan yang sesuai standar, namun motivasi para guru menjadi menurun ketika sekolahsekolah tersebut dihimbau untuk kembali kepada KTSP.

Respon para guru di Perguruan Muhammadiyah Wiyung Surabaya terhadap pelaksanaan PKM di lembaga tersebut dijaring melalui wawancara tentang respon para guru di Perguruan Muhammadiyah Wiyung Surabaya terhadap pelaksanaan kegiatan PKM di lembaga tersebut yang dapat dirangkum dalam Tabel 4 berikut.

Tabel 4. Respon Para Guru Terhadap Pelaksanaan PKM

\begin{tabular}{lccc}
\hline \multicolumn{1}{c}{ Aspek yang dinilai } & \multicolumn{2}{c}{ Guru yang memberi apresiasi baik } \\
\cline { 2 - 4 } & SDM 15 & SMPM 17 & SMAM 9 \\
\hline Durasi waktu pendampingan & $100 \%$ & $100 \%$ & $100 \%$ \\
\hline Kesesuaian waktu pendampingan dengan jadwal sekolah & $100 \%$ & $100 \%$ & $100 \%$ \\
\hline Penguasan materi dari narasumber & $100 \%$ & $100 \%$ & $100 \%$ \\
\hline Penguasaan narasumber terhadap prinsip pendampingan & $100 \%$ & $100 \%$ & $100 \%$ \\
\hline Kesesuaian materi pendampingan dengan kebutuhan guru & $100 \%$ & $100 \%$ & $100 \%$ \\
\hline Menambah wawasan guru tentang prinsip-prinsip penilaian & $100 \%$ & $100 \%$ & $100 \%$ \\
\hline Menambah kemampuan guru dalam melaksanakan penilaian & $100 \%$ & $100 \%$ & $100 \%$ \\
\hline Menindaklanjuti hasil pendampingan yang diperoleh & $100 \%$ & $100 \%$ & $100 \%$ \\
\hline
\end{tabular}

Berdasarkan hasil wawancara di atas, para guru tampaknya memberikan apresiasi yang sangat baik terhadap pelaksanaan PKM di lembaga tersebut. Semua guru memberikan respon yang sangat baik terhadap berbagai pertanyaan terkait pelaksanaan PKM di lembaga tersebut. Para guru di lembaga tersebut berharap agar kegiatan PKM dapat dilanjutkan dengan materi pendampingan lainnya yang berkaitan dengan pengembangan profesionalisme guru.

\section{SIMPULAN DAN SARAN}

Dari kegiatan "Pendampingan Implementasi Penilaian Pendidikan Bagi GuruGuru di Perguruan Muhammadiyah Wiyung Surabaya" dapat ditarik beberapa kesimpulan sebagai berikut: 
1. Semua guru di SD Muhammadiyah 15 Surabaya telah mempunyai pemahaman yang baik terhadap penilaian pendidikan yang sesuai standar, sedangkan guru di SMP Muhammadiyah 17 Surabaya dan guru di SMA Muhammadiyah 9 Surabaya sebagian kecil saja yang memahami.

2. Semua guru di SD Muhammadiyah 15 Surabaya telah mengembangkan instrumen penilaian pendidikan beserta rubriknya yang sesuai standar, sedangkan guru di SMP Muhammadiyah 17 Surabaya dan guru di SMA Muhammadiyah 9 Surabaya sebagian kecil saja yang mengembangkan.

3. Semua guru di SD Muhammadiyah 15 Surabaya telah mengimplementasikan penilaian pendidikan yang sesuai standar, sedangkan guru di SMP Muhammadiyah 17 Surabaya dan guru di SMA Muhammadiyah 9 Surabaya sebagian kecil saja yang mengimplementasikan.

4. Semua guru di Perguruan Muhammadiyah Wiyung Surabaya memberikan respon yang baik terhadap pelaksanaan PKM di lembaga tersebut.

Kegiatan ini hendaknya dapat ditindaklanjuti dengan melakukan workshop secara berkala mengenai pengembangan instrumen beserta rubriknya yang dapat memacu para guru untuk mengembangkan pembelajaran yang aktif, inovatif, kreatif, efektif, dan menyenangkan (PAIKEM), dengan menerapkan teknik-teknik penilaian yang bervariasi.

\section{DAFTAR PUSTAKA}

Kemdikbud. 2012. Pengantar Uji Publik Pengembangan Kurikulum 2013. Kementerian Pendidikan dan Kebudayaan, Desember 2012.

Kustijono, R. 2014. Implementasi Kurikulum 2013 Untuk Pembelajaran IPA SMP Di Kabupaten Sampang dan Lumajang, Prosiding Seminar Pendidikan Sains 2014, Program Pascasarjana Unesa Surabaya.

Permendikbud No. 66 Tahun 2013 tentang Standar Penilaian Pendidikan.

Permendikbud No. 104 tahun 2014 tentang Standar Penilaian Pendidikan.

Ruiz M.A., Primo. 2009. Towards a Framework for Assessing 21st Century Science Skills, Commissioned paper for The National Academies, University of Colorado Denver, February, 2009

Sharp, C. 2004. Developing young children's creativity, what can we learn from research

Trilling, B. dan Hood, P. 1999. Learning, Technology, and Education Reform in the Knowledge Age or "We're Wired, Webbed, and Windowed, Now What"? Educational Technology MayJune 1999. 